\title{
Carbon transformations by attached bacterial populations in granitic groundwater from deep crystalline bed-rock of the Stripa research mine
}

\author{
Susanne Ekendahl and Karsten Pedersen \\ Author for correspondence: Susanne Ekendahl. Tel: +46 3177325 86. Fax: +46 317732599 \\ e-mail: Ekendahl@gmm.gu.se
}

Department of General and Marine Microbiology, University of Göteborg, Medicinaregatan 9C, S-413 90 Göteborg, Sweden
This paper presents and compares the assimilation rates of $\mathrm{CO}_{2}$ and lactate, and the lactate respiration rates, of attached bacterial populations growing in slowly flowing groundwater (1-3 $\left.\mathrm{mm} \mathrm{s}^{-1}\right)$ from deep crystalline bed-rock of the Stripa research mine, Sweden. The bacteria studied grew in anoxic, high-pH (9-10) and low-redox artesian groundwater flowing up through tubing from two levels of a borehole designated V2, 812-820 m and 970-1240 m below ground. Bacteria were allowed to attach to and grow on sterile glass microscope slides in laminar-flow reactors connected to the flowing groundwater. Total numbers of bacteria were counted by acridine orange direct counts. The bacteria grew slowly, with doubling times of $34 \mathrm{~d}$ at $10{ }^{\circ} \mathrm{C}$ for the 812-820 $\mathrm{m}$ population, $23 \mathrm{~d}$ for the $970-1240 \mathrm{~m}$ population at $10{ }^{\circ} \mathrm{C}$ and $16 \mathrm{~d}$ for this population at $20^{\circ} \mathrm{C}$. Numbers of attached bacteria reached between $10^{6}$ and $10^{7}$ bacteria $\mathrm{cm}^{-2}$. The populations at the two levels of the borehole were different in physiology as well as in phylogeny and reflected the heterogeneity between the sampling levels. The earlier proposed presence of sulphate-reducing bacteria could not be confirmed. This is discussed in relation to results from 165 rRNA gene sequencing studies. The $\mathrm{CO}_{2}$ assimilation rates (as mol $\mathrm{CO}_{2} \mathrm{~cm}^{-2} \mathrm{~h}^{-1}$, using liquid scintillation techniques) increased with depth and temperature. The quotients calculated for inorganid/organic carbon utilization were between 0.07 and 0.25 , indicating that autotrophy could not support the levels of growth observed and that heterotrophy was the dominant carbon transformation process for growth of the studied populations. The Stripa bacteria could further be seen not only to assimilate but also to catabolize lactate and release $\mathrm{CO}_{2}$, which added to the indications of a heterotrophic dominance in the Stripa environment.

Keywords: deep groundwater, carbon dioxide assimilation, lactate respiration, attached bacteria, heterotrophy

\section{INTRODUCTION}

Radioactive waste from nuclear power plants has to be processed and safely deposited in repositories. The present Swedish concept is to encapsulate the waste in steelcopper canisters and surround them with bentonite in crystalline bed-rock, $500 \mathrm{~m}$ below ground (SKB, 1991). During 1987, a research project on microbial processes in deep groundwater systems was initiated at the department of General and Marine Microbiology at the University of Göteborg. Our results (Pedersen \& Ekendahl, 1990,

Abbreviations: AODC, acridine orange direct counts; SRB, sulphatereducing bacteria; TIC, total inorganic carbon. 1992a, b) and those of others (Erlich, 1990; Gold, 1992; Pedersen, 1993; Pedersen \& Albinsson, 1992; Stevens $e t$ al., 1993; West $e$ t al., 1982, 1985) clearly demonstrate that microbes may be involved in many subterranean geochemical processes, such as diagenesis, weathering and precipitation, and in oxidation/reduction reactions of metals, carbon, nitrogen and sulphur - just as they are in most terranean environments. The aim of the project is to understand how subterranean bacteria interact with these processes during and after the construction of a nuclear waste repository, so as to achieve the safest possible disposal of high-level nuclear waste. The project comprises studies on several interacting microbial processes in groundwater that are important for the performance safety assessment of nuclear waste disposal. Bacteria are 
inevitably interacting with the carbon cycle, thereby affecting $\mathrm{pH}$, redox potential and the organic content of the groundwater. The proposed presence of sulphatereducing bacteria in groundwater (Fontes et al., 1989; Fritz et al., 1989; Pedersen \& Ekendahl, 1992a) would mean the possible risk of canister corrosion through their production of hydrogen sulphide. Growth of bacteria on fracture surfaces and their participation in the formation of fracture minerals, weathering and radionuclide sorption to the rock may also be influential.

Our field investigations have been focused on the Stripa research mine, a former iron ore mine in south central Sweden. We found active bacteria in the anoxic groundwater from the deep granite bed-rock of Stripa (Pedersen \& Ekendahl, 1992a) that assimilated carbon dioxide and thus had an autotrophic potential for in situ production of organic carbon. They incorporated introduced formate, glucose and leucine; and the incorporation of lactate was especially high, demonstrating a heterotrophic potential. Bacteria attached to glass surfaces were more active than unattached bacteria in the water.

In this work we have measured the rates of $\mathrm{CO}_{2}$ and lactate assimilation, lactate respiration and biofilm development on glass surfaces in slowly flowing anoxic groundwater from depths ranging from 800 to $1200 \mathrm{~m}$ in a borehole in the Stripa research mine. We compared the results both within and between the populations studied. Attempts were also made to determine whether sulphate reduction was performed by the attached bacteria. Possible effects of attached bacterial populations on the carbon cycle in groundwater from deep crystalline bed-rock are discussed, as well as possible bacterial groups.

\section{METHODS}

Study site. This study was performed in the Stripa research mine in Guldsmedshyttan, Västmanland, Sweden. The mine contained iron ore, a quartz-banded haematite occurring in a lepatite formation, which was mined out in 1976. The mine was then used for underground research, for both national and international (OECD/NEA) studies, until it was closed in 1991.

Experimental set-up. The borehole V2 $(76 \mathrm{~mm}$ wide) was drilled subvertically through medium-grained granite adjacent to the lepatite from a mine drift $410 \mathrm{~m}$ below ground to $860 \mathrm{~m}$ in 1977 and continued to $1240 \mathrm{~m}$ in 1981 . The borehole had an average of about two fractures per metre of rock. The flowing groundwater studied came from two levels of this borehole, $812-820 \mathrm{~m}$ and $970-1240 \mathrm{~m}$. The levels were closed off with packers made of inflatable $76 \mathrm{~mm}$ rubber tubes. The artesian water from these levels has been continually flowing up to the drift through $6 \mathrm{~mm}$ teflon tubing since 1990 and its chemical composition has been well characterized (Nordström et al., 1985). Laminar-flow reactors (Pedersen, 1982; Pedersen et al., 1986) were connected to the slowly flowing anoxic groundwaters at flows of approximately $1 \times 10^{-3} \mathrm{~m} \mathrm{~s}^{-1}$, as shown in Fig. 1. Each reactor contained $12+24$ parallel hydrophilic microscope glass slides, $60 \times 24 \times 1$ and $40 \times 24 \times 1 \mathrm{~mm}$, respectively. The glass slides had been heated in a muffle furnace at $475{ }^{\circ} \mathrm{C}$ for $4 \mathrm{~h}$. The waters were chilled to $10^{\circ} \mathrm{C}$ when flowing through the tubing up to the drift. The $970-1240 \mathrm{~m}$

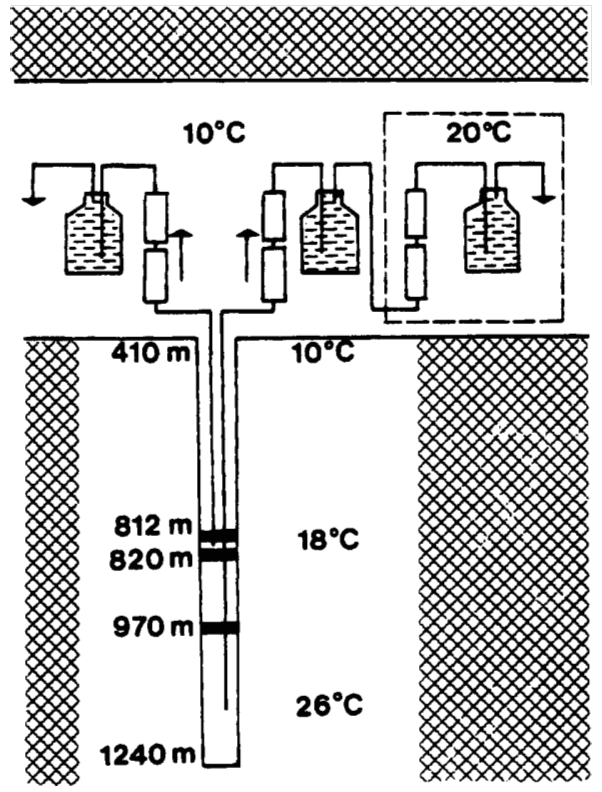

Fig. 1. Experimental setup with laminar-flow reactors connected to flowing groundwater from the Stripa borehole V2.

groundwater was re-heated to $20^{\circ} \mathrm{C}$ in a hut in the drift to imitate the in situ temperature in the borehole (Fig. 1). The flowing waters were collected from sterile 51 glass bottles connected to the laminar-flow reactors. All water used for measurements and incubations was taken from these bottles unless otherwise noted.

Water analysis. The $\mathrm{pH}$ and the $E_{\mathrm{h}}$ were measured in situ in the mine with a PHM Autocal $\mathrm{pH}$ meter (Radiometer), a GK2421C combined $\mathrm{pH}$ electrode and redox electrode PK1401. Sulphate was measured turbidimetrically with $\mathrm{BaCl}_{2}$ (Franson, 1985), sulphide by an iodometric method (Franson, 1985) and the total inorganic carbon (TIC) contents were measured with a coulometer (model $5011 \mathrm{CO}_{2}$ Coulometer) (Huffman, 1977). These procedures were repeated at a $30 \mathrm{~d}$ interval.

Oxygen was measured as follows. Winkler bottles for each level and temperature were filled with groundwater under $\mathrm{N}_{2}$ atmosphere. The bottles were stored at $+4{ }^{\circ} \mathrm{C}$ and a modified form of the common Winkler method was used for the analysis (Carritt \& Carpenter, 1972). Measurements of other gases are reported in Pedersen et al. (1991).

Total numbers of unattached and attached bacteria. Acridine orange stained direct counts (AODC) were used to determine the total numbers of unattached bacteria, as described earlier (Pedersen \& Ekendahl, 1990). Groundwater bacteria were allowed to attach to and grow on the glass slides in the laminarflow reactors for up to $161 \mathrm{~d}$ for the $812-820 \mathrm{~m}$ level (January to June 1991) and $90 \mathrm{~d}$ for the $970-1240 \mathrm{~m}$ level (April to June 1991). The bacteria were stained in acridine orange, rinsed with distilled water and the total number of cells was counted.

Assimilation of $\mathrm{CO}_{2}$. Incubations for assimilation measurements were done anaerobically since the groundwater was essentially anaerobic. Groundwater, sampled from the two borehole levels, was pressure filtered in $20 \mathrm{ml}$ volumes under $\mathrm{N}_{2}$ atmosphere 
through Dynagard hollow-fibre syringe filters (pore size $0.2 \mu \mathrm{m}$ ), into sterile $50 \mathrm{ml}$ polypropylene centrifuge tubes with lids (Nunc). Microscope slides from the laminar-flow reactors were transferred under nitrogen atmosphere to tubes with corresponding filtered groundwater, one slide per tube. Labelled carbonate, $\mathrm{Na}_{2}{ }^{14} \mathrm{CO}_{3}$ (Amersham Sweden), was subsequently added in $1 \mathrm{ml}$ oxygen-free portions to assay the $\mathrm{CO}_{2}$ assimilation of the populations studied. The specific activity used was $2.06 \times 10^{9} \mathrm{~Bq} \mathrm{mmol}^{-1}$ and the final concentration of labelled $\left[{ }^{14} \mathrm{C}\right]$ carbonate in the tubes was $20 \mu \mathrm{M}$. This chosen concentration was high so as to permit detection of assimilation by few bacteria having low activities and slow growth. The unlabelled TIC concentration in the groundwater was $50 \mu \mathrm{M}$ at the $812-820 \mathrm{~m}$ level, and $57 \mu \mathrm{M}$ at $970-1240 \mathrm{~m}$ (Table 1). Thus the summed TIC concentrations (labelled and unlabelled) in the tubes were 70 and $77 \mu \mathrm{M}$, respectively. One millilitre of an unlabelled oxygen-free lactate solution $(\mathrm{pH} 10$, final concentration $10 \mu \mathrm{M}$ ) was added as an organic carbon source to one set of tubes. The microscope slides were incubated horizontally for $1-4 \mathrm{~h}$ at 10 or $20^{\circ} \mathrm{C}$ with slow shaking, after which formalin was added to a final concentration of $2 \%(\mathrm{v} / \mathrm{v})$. Controls for abiotic adsorption of the labelled carbonate were achieved by addition of formalin $(2 \%)$ to clean and sterile sample slides together with the labelled compound at sampling, and processing them as the other samples. Subsequently, each slide was rinsed with a surface rinse (Pedersen et al., 1986) containing distilled water with $1 \%(\mathrm{w} / \mathrm{v}) \mathrm{NaCl}(\mathrm{pH} 3 \cdot 0)$, cut into four pieces (Pedersen \& Ekendahl, 1992b), placed in $20 \mathrm{ml}$ scintillation cocktail (Ready Safe, Beckman) and radioactivity measured in a Beckman LS 3801 scintillation counter. Control counts were subtracted from sample counts.

Doubling the ${ }^{14} \mathrm{C}$ concentration in the tubes from 20 to $40 \mu \mathrm{M}$ resulted in a corresponding increase in ${ }^{14} \mathrm{C}$ assimilation, but the uptake rate was not affected by this concentration change. The isotope contents of the liquid in the tubes were measured just before the addition of formalin by taking out $0.1 \mathrm{ml}$ into $10 \mathrm{ml}$ Ready Safe. The total radioactivity in each tube was calculated as the sum of the radioactivity in the liquid and on the glass slide. The sums were equal to the added amounts and had a standard deviation of between 2.4 and $6.2 \%$ of the mean value with $20 \mu \mathrm{M}$ and of $13 \%$ with $40 \mu \mathrm{M}$, showing that the added isotope did not disappear during the experiment and that the tubes had similar ${ }^{14} \mathrm{C}$ activities.

During sampling, $\mathrm{pH}$ and $E_{\mathrm{h}}$ were measured in situ in series parallel with the assimilation experiments to check that incubation conditions were constant. Tubes were prepared without slides but with unlabelled compounds added to the filtered groundwaters. $\mathrm{pH}$ in the tubes decreased somewhat (maximum 0.6 units) during incubation. The redox potentials were stable. Temperature had no detectable influence on either $\mathrm{pH}$ or $E_{\mathrm{n}}$.

Calculations of $\mathrm{CO}_{2}$ assimilation/total cell carbon ratios. The quotient between $\mathrm{CO}_{2}$ assimilated and carbon demanded for growth was calculated as follows. The carbon content of meansized bacteria was calculated from their volumes. This was done by measuring the length and width of the bacteria with a ruler directly on slide projections with biofilm bacteria from the reactors. Two slides from each level and temperature were used, and 50 cells were measured on each of them. The volume per bacterium $(V)$ was calculated according to Grigorova \& Norris (1990):

$V=(\pi / 4) \cdot D^{2} \cdot(L-D / 3)$

where $D$ is width and $L$ is length.
A conversion factor for the calculation of the carbon content of a mean-sized bacterium was determined by multiplying a $30 \%$ dry weight of a cell (Neidhardt $e t$ al., 1990), a $50 \%$ dry weight carbon content (Neidhardt et al., 1990; Stanier et al., 1990) and an assumed bacterial density similar to water of $1 \times 10^{-12} \mathrm{~g} \mathrm{\mu m}^{-3}$. The conversion factor, $F$, calculated in this way, was

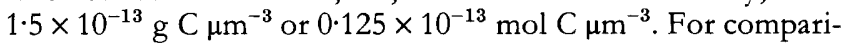
son, Grigorova \& Norris (1990) compiled several direct biomass estimations where a majority of the investigators had used epifluorescence microscopy for cell volume estimates and CHN analyses for cell carbon measurements. These conversion factors

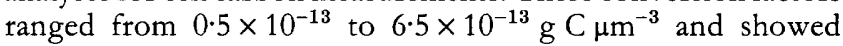
large coefficients of variation. Grigorova \& Norris (1990) recommend the average conversion factor $3 \cdot 1 \times 10^{-13} \mathrm{~g} \mathrm{C}$ per $\mu \mathrm{m}^{3}$ of bacteria.

The measured amount of carbon assimilated per bacterium at a density of $1.8 \times 10^{6}$ cells cm $\mathrm{cm}^{-2}$ was divided by the carbon demanded for growth for one bacterium, taking into consideration the doubling time of the population. This quotient, here called $Q$, shows the autotrophic potential of the population. The following formulae were used:

$Q=A / B$

where $A$ is assimilated carbon as mol $\mathrm{C}$ per bacterium per hour (results taken from Table 3 ) and $B$ is carbon demanded for growth, and

$B=(F \cdot V \cdot k) /(\log 2 \cdot 24)$

where $F$ is the conversion factor (see above) and $V$ is cell volume, and $k$ is the bacterial growth rate constant, determined from linear regressions during the growth period from day 27 onwards.

Lactate assimilation and respiration. Lactate assimilation of attached bacteria was measured with the same tube setup and methods as in the $\mathrm{CO}_{2}$ incubations, i.e. with $20 \mathrm{ml}$ filtered groundwater and one glass slide in each tube. The tubes contained $1 \mathrm{ml}$ of 1.0 or $2.5 \mu \mathrm{M}\left[\mathrm{U}_{-}{ }^{14} \mathrm{C}\right]$ lactate, specific activity $5.69 \times 10^{9} \mathrm{~Bq} \mathrm{mmol}^{-1}$, and were closed with rubber stoppers and incubated anaerobically as described before. Respiration was measured as shown in Fig. 2. To each tube with labelled lactate $0.8 \mathrm{ml} 0.3 \mathrm{M} \mathrm{HCl}$ was added after incubation. The tubes were shaken, $\mathrm{N}_{2}$ gas was bubbled through for $15 \mathrm{~min}$ and the released ${ }^{14} \mathrm{CO}_{2}$ originating from the respired lactate was precipitated in $20 \mathrm{ml}$ serum bottles preceded by an empty safety bottle. The three traps each contained $10 \mathrm{ml} 1.9 \mathrm{M} \mathrm{KOH}$. Two subsamples of 0.1 and $1 \mathrm{ml}$ were taken from each trap and put

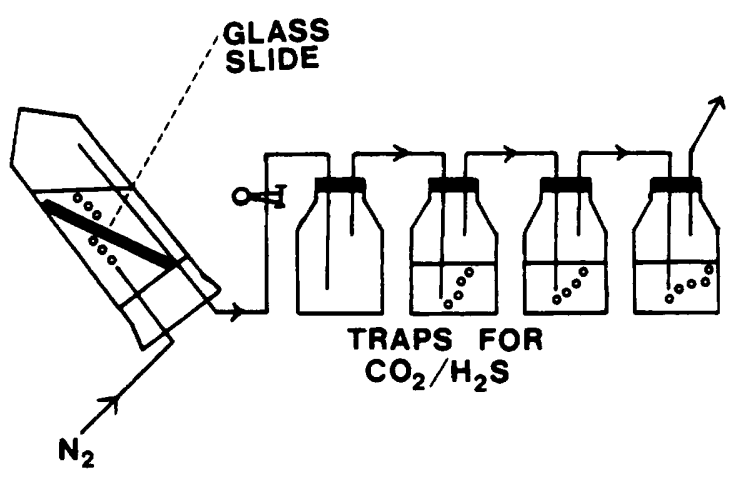

Fig. 2. Experimental setup for measuring lactate respiration and sulphate reduction. 
Table 1. Major parameters of the Stripa borehole V2

\begin{tabular}{|lccccccccc|}
\hline $\begin{array}{l}\text { Sampling } \\
\text { depth } \\
(\mathbf{m})\end{array}$ & $\mathbf{p H}$ & $\begin{array}{c}E_{\mathrm{h}} \\
(\mathbf{m V})\end{array}$ & $\begin{array}{c}\text { Temp.* } \\
\left({ }^{\circ} \mathbf{C}\right)\end{array}$ & $\begin{array}{c}\mathbf{S O}_{4}^{2-} \\
(\boldsymbol{\mu M})\end{array}$ & $\begin{array}{c}\mathbf{S}^{2-} \\
(\boldsymbol{\mu M})\end{array}$ & $\begin{array}{c}\text { TIC } \\
(\boldsymbol{\mu} \mathbf{M})\end{array}$ & $\begin{array}{c}\mathbf{O}_{2} \\
(\boldsymbol{\mu} \mathbf{M})\end{array}$ & $\begin{array}{c}\text { Conductivity } \\
\left(\boldsymbol{\mu} \mathbf{S} \mathbf{c m}^{-1}\right)\end{array}$ & $\begin{array}{c}\text { Flow rate } \\
\left(\mathbf{m ~ s}^{-\mathbf{1}}\right)\end{array}$ \\
\hline $812-820$ & $9 \cdot 4$ & +199 & 18 & 1433 & 106 & 50 & $3 \cdot 4$ & 1640 & $2 \cdot 8 \times 10^{-3}$ \\
$970-1240$ & $10 \cdot 2$ & -3 & 26 & 520 & 233 & 57 & 0 & 1180 & $0 \cdot 5 \times 10^{-3}$ \\
\hline
\end{tabular}

* At sampling depth in the borehole.

into glass vials with $10 \mathrm{ml}$ scintillation cocktail (Hionic Fluor, Packard). The radioactivity was measured as d.p.m. in the scintillation counter. Background controls were made with $0 \cdot ?$ and $1 \mathrm{ml}$ of the $\mathrm{KOH}$ solution in Hionic Fluor and subtracted from sample counts. Then the slides were cut as described for $\mathrm{CO}_{2}$ assimilation. Also, duplicate controls showed that lactate did not release $\mathrm{CO}_{2}$ when $\mathrm{HCl}$ was added. The closed tubes did not release any $\mathrm{CO}_{2}$. The total isotope content in each tube (radioactivity in the liquid and on the glass slide), was measured after the respiration measurements. The values had a standard deviation of between 3.5 and $8.4 \%$ of the mean and showed that the added concentration in the tubes was reproducible and that the isotope did not disappear during the experiment.

Sulphate assimilation and reduction. Sulphate assimilation and reduction to sulphide were measured with a tube setup similar to that for lactate respiration $(20 \mathrm{ml}$ filtered groundwater, one slide and $1 \mathrm{ml}$ oxygen-free isotope solution per tube) and the methods used for lactate assimilation and respiration measurements (see Fig. 2), but with the following changes. The isotope was $\mathrm{Na}_{2}{ }^{35} \mathrm{SO}_{4}$ with a specific activity of $4 \times 10^{7} \mathrm{MBq} \mathrm{mmol}^{-1}$, giving a final concentration of ${ }^{35} \mathrm{~S}$ in the tubes of 2.8 or $4.2 \mathrm{nM}$. The tubes also contained $1 \mathrm{ml}$ unlabelled lactate to a final concentration of $10 \mu \mathrm{M}$. The sulphate reduction was stopped by precipitating $\mathrm{H}_{2} \mathrm{~S}$ with $5 \mathrm{ml} 20 \%$ (w/v) zinc acetate (Fossing \& Jörgensen, 1989) and the tubes were immediately frozen on dry ice. Acidification (giving a $\mathrm{pH}$ below 2) was done with $1.5 \mathrm{ml} 5 \mathrm{M} \mathrm{HCl}$. The traps contained $10 \mathrm{ml}$ $5 \%$ zinc acetate $+0.1 \%$ acetic acid (Fossing \& Jörgensen, 1989). $\mathrm{N}_{2}$ was bubbled through for $30 \mathrm{~min}$. From each of three traps $3 \mathrm{ml}$ subsamples were mixed with $15 \mathrm{ml}$ Hionic Fluor. Testing the method with sulphate reducers previously isolated from another groundwater (Pedersen \& Ekendahl, 1990) and subcultured in the laboratory showed that the method worked very well.

\section{RESULTS}

\section{Chemistry of the groundwaters}

The results from the water analysis are shown in Table 1. These data differ between the sampling depths, indicating that the groundwaters were obtained from fracture systems with no close hydraulic connections.

\section{Growth and total number of bacteria}

The total numbers of unattached bacteria are presented in Table 2. There were more bacteria present at the deeper level; the variation in the numbers of bacteria was low between the sampling occasions. Fig. 3 shows total
Table 2. Total numbers of unattached bacteria of the Stripa borehole V2

\begin{tabular}{|c|c|c|c|}
\hline \multirow{2}{*}{$\begin{array}{l}\text { Sampling } \\
\text { date } \\
(1991)\end{array}$} & \multirow[t]{2}{*}{$N^{*}$} & \multicolumn{2}{|c|}{$10^{-5} \times$ Bacteria $\mathrm{ml}^{-1} \dagger$} \\
\hline & & $812-820 \mathrm{~m}$ & $970-1240 \mathrm{~m}$ \\
\hline \multicolumn{4}{|c|}{$\begin{array}{l}\text { Groundwater } \\
\text { sampling }\end{array}$} \\
\hline 15 April & 3 & $0 \cdot 13(59)$ & $3 \cdot 4(21)$ \\
\hline 29 May & 2 & $0 \cdot 23(14)$ & $2 \cdot 5(11)$ \\
\hline 25 June & 2 & $0.22(49)$ & $1 \cdot 4(79)$ \\
\hline
\end{tabular}

$* \mathrm{~N}$ is the number of independent samples.

t SD (\%) shown in parentheses.

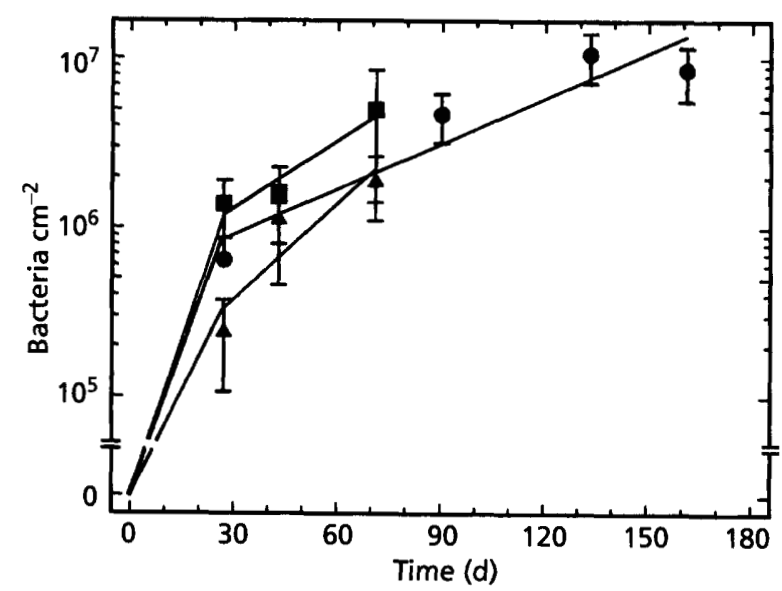

Fig. 3. Total number of attached bacteria on surfaces exposed to flowing groundwater from the Stripa borehole V2 for different times. $0,812-820 \mathrm{~m}, 10^{\circ} \mathrm{C} ; \boldsymbol{\square}, 970-1240 \mathrm{~m}, 10^{\circ} \mathrm{C} ; \boldsymbol{\Delta}$, $970-1240 \mathrm{~m}, 20^{\circ} \mathrm{C}$.

numbers of bacteria on slides after attachment and growth for up to $161 \mathrm{~d}$. The bacteria appeared in micro-colonies on the surfaces, which indicates growth. This is shown on SEM images in Fig. 1 of Ekendahl et al. (1994). The total numbers after $43 \mathrm{~d}$ were between $10^{6}$ and $10^{7}$ bacteria $\mathrm{cm}^{-2}$, as compared to total numbers in the liquid phase in the region of $10^{4} \mathrm{ml}^{-1}$ for $812-820 \mathrm{~m}$ and $10^{5} \mathrm{ml}^{-1}$ for 


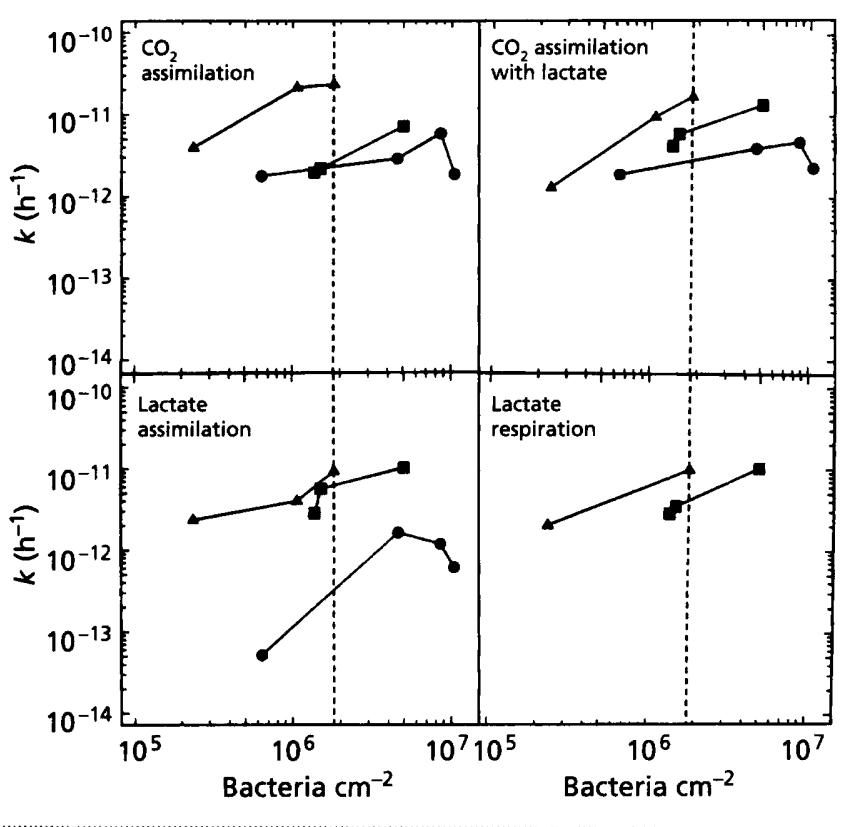

Fig. 4. In situ assimilation rates of $\mathrm{CO}_{2}$ without and with the addition of $10 \mu \mathrm{M}$ unlabelled lactate, assimilation rates of ${ }^{14} \mathrm{C}$ from $\left[\mathrm{U}-{ }^{14} \mathrm{C}\right]$ lactate, and respiration rates of assimilated $\left[{ }^{14} \mathrm{C}\right]$ lactate, measured as ${ }^{14} \mathrm{CO}_{2}$ evolution, by attached bacteria in groundwater from the Stripa borehole V2., $812-820 \mathrm{~m} ; \mathrm{C}$, 970-1240 $\mathrm{m}, 10^{\circ} \mathrm{C} ; A, 970-1240 \mathrm{~m}, 20^{\circ} \mathrm{C}$. The dashed line in each panel represents $1.8 \times 10^{6}$ bacteria $\mathrm{cm}^{-2}$, and is used for calculations of $\mathrm{CO}_{2}$ assimilation rates in Table 3 .

970-1240 m. Linear regression from the 27 th day onward gave doubling times for the populations; these are shown in Table 4. The correlation coefficients, $r$, and probabilities, $p$, for $812-820 \mathrm{~m}, 970-1240 \mathrm{~m}\left(10\right.$ and $\left.20^{\circ} \mathrm{C}\right)$, were 0.94 and $0.06,0.96$ and $0.19,0.91$ and 0.28 , respectively.

\section{Assimilation of $\mathrm{CO}_{2}$, lactate assimilation and respiration}

The assimilation of $\mathrm{CO}_{2}$ and lactate, and respiration of the added lactate to $\mathrm{CO}_{2}$ was plotted against the incubation time (4 h, not shown). A detailed description of the calculation criteria is given by Pedersen \& Ekendahl (1992b). Briefly, assuming that the assimilation was correlated with time, only data that in a linear regression had a correlation coefficient larger than 0.7 and a significance level larger than $95 \%$ were further examined. We assumed the slope of each line to reveal the in situ rate of assimilation and respiration, as $\mathrm{mol} \mathrm{cm} \mathrm{cm}^{-2} \mathrm{~h}^{-1}$. These rates are summarized in Fig. 4, and presented in detail by Pedersen et al. (1991). Generally the rates were higher when there were more bacteria present. The bacteria did assimilate $\mathrm{CO}_{2}$ and lactate and also respired lactate into $\mathrm{CO}_{2}$.

Table 3 compares rates of assimilation and respiration by an average attached bacterium at a density of $1 \cdot 8 \times 10^{6} \mathrm{~cm}^{-2}$ in the different populations. The rates were higher in the population from $970-1240 \mathrm{~m}$ than in that from $812-820 \mathrm{~m}$. Raised temperature gave higher assimilation rates.

\section{$\mathrm{CO}_{2}$ assimilation/total cell carbon ratios}

The evaluation of the quotient $Q$ between $\mathrm{CO}_{2}$ assimilated and carbon demanded for growth gave the results shown in Table 4. For example, in the $812-820 \mathrm{~m}$ population, the doubling time was $34 \mathrm{~d}$ (assuming that growth from days 27-161 was linear). This gives the result that one bacterium demanded $1.42 \times 10^{-17} \mathrm{~mol} \mathrm{C}$ per hour to be built up. The $\mathrm{CO}_{2}$ assimilation rate was $1.2 \times 10^{-18} \mathrm{~mol} \mathrm{C}$ per bacterium per day at a density of $1.8 \times 10^{6}$ bacteria $\mathrm{cm}^{-2}$ (Table 3). The quotient $Q$ was 0.09 (Table 4). For the $970-1240 \mathrm{~m}$ population at $10^{\circ} \mathrm{C}$ the corresponding quotient was 0.07 and for this population at

Table 3. In situ assimilation rates of $\mathrm{CO}_{2}$ without and with the addition of $10 \mu \mathrm{M}$ unlabelled lactate, assimilation rates of ${ }^{14} \mathrm{C}$ from $\left[\mathrm{U}-{ }^{14} \mathrm{C}\right]$ lactate, and respiration rates of assimilated $\left[{ }^{14} \mathrm{C}\right]$ lactate, measured as ${ }^{14} \mathrm{CO}_{2}$ evolution, by an average attached bacterium at a density of $1.8 \times 10^{6}$ bacteria $\mathrm{cm}^{-2}$

All assimilation and respiration rates are expressed as $\times 10^{-18} \mathrm{~mol} \mathrm{~h}^{-1}$ per bacterium. ND, Not determined.

\begin{tabular}{|lccccc|}
\hline $\begin{array}{l}\text { Depth } \\
(\mathrm{m})\end{array}$ & $\begin{array}{c}\text { Temp. } \\
\left({ }^{\circ} \mathbf{C}\right)\end{array}$ & $\begin{array}{c}\mathbf{C O}_{2} \\
\text { assimilation }\end{array}$ & $\begin{array}{c}\mathbf{C O}_{2} \\
\text { assimilation } \\
\text { with } \\
\mathbf{1 0} \boldsymbol{\mu} \mathbf{M} \\
\text { lactate }\end{array}$ & $\begin{array}{c}\text { Lactate } \\
\text { assimilation }\end{array}$ & $\begin{array}{c}\text { Lactate } \\
\text { respiration }\end{array}$ \\
& & & $1 \cdot 6$ & $0 \cdot 2$ & \\
\hline $812-820$ & 10 & $1 \cdot 2$ & 3.6 & $6 \cdot 0$ & ND \\
$970-1240$ & 10 & 1.6 & $9 \cdot 5$ & $9 \cdot 1$ & $5 \cdot 4$ \\
$970-1240$ & 20 & 12.9 & & & \\
\hline
\end{tabular}


Table 4. Data for and calculation of the autotrophic capability of the Stripa populations

For a detailed description, see text.

\begin{tabular}{|c|c|c|c|c|c|c|}
\hline $\begin{array}{l}\text { Level } \\
\text { (m) }\end{array}$ & $\begin{array}{c}\text { Temp. } \\
\left({ }^{\circ} \mathrm{C}\right)\end{array}$ & $\begin{array}{l}\text { Doubling } \\
\text { time } \\
\text { (d) }\end{array}$ & $\begin{array}{c}\text { Cell } \\
\text { volume, } \\
\underset{\left(\mu \mathrm{m}^{3}\right)}{V}\end{array}$ & $\begin{array}{c}\text { Carbon } \\
\text { assimilated } \\
(A)^{* \dagger}\end{array}$ & $\begin{array}{l}\text { Carbon } \\
\text { required } \\
\text { for growth } \\
\text { (B) } \dagger\end{array}$ & $\begin{array}{c}\text { 'Autotrophy', } \\
Q \\
(=A / B)\end{array}$ \\
\hline $812-820$ & 10 & 34 & 0.92 & $1 \cdot 2$ & $14 \cdot 2$ & 0.09 \\
\hline $970-1240$ & 10 & 23 & $1 \cdot 01$ & 1.6 & $23 \cdot 1$ & 0.07 \\
\hline $970-1240$ & 20 & 16 & 1.59 & $12 \cdot 9$ & $51 \cdot 9$ & 0.25 \\
\hline
\end{tabular}

* From Table 3. † Expressed as $\times 10^{-18} \mathrm{~mol} \mathrm{C} \mathrm{h}^{-1}$ per bacterium.

$20{ }^{\circ} \mathrm{C}$ it was $0 \cdot 25$ (days $27-71$ ). All quotients are well below 1 , indicating that autotrophy is far from enough to supply these populations with carbon for growth.

\section{Sulphate assimilation and reduction}

Only a few of the slides showed sulphate assimilation that was more than $50 \%$ higher than in the controls. There was no detectable production of sulphide in any of the tubes.

\section{DISCUSSION}

The laminar flow reactors have been shown to constitute a reproducible environment for the study of attachment and growth of bacteria (Pedersen, 1982). The experimental variance is very low, making the reactors well suited for comparisons between environments as were done here. Except for pressure and temperature, the reactor environments were believed to parallel the in situ chemical and physical environments reasonably well to make such a comparison valid. One of the most important factors governing attachment and growth of bacteria is the bacterial species itself (Pedersen et al., 1986). Depending on species and strain, different attachment patterns are obtained. The opposite process, separation from the surface, occurs during multiplication of irreversibly attached bacteria and as desorption of reversibly attached bacteria in laminar flow systems (Escher \& Characklis, 1990). Here, the reactors were used as a first approximation of a fracture surface system with the assumption that some of the dominant bacteria growing on fracture surfaces in the deep environment will detach, move with the flowing water, attach and grow again, eventually in the reactor environment imitating the in situ situation.

Both the chemical data and the bacterial numbers counted in the Stripa groundwater reflect a heterogeneity between the sampled levels. This heterogeneity was also observed when the salinity profile was studied (Nordström et al., 1985). It indicates that the groundwaters came from fracture systems without close interconnections. The content of sulphide and trace amounts of oxygen in the groundwater from the $812-820 \mathrm{~m}$ level indicates that this water might have been a mix of oxic and anoxic waters from different fractures. The study of the attached Stripa populations using 16S rRNA gene sequencing (Ekendahl et al., 1994) revealed that there were different populations at each of the two levels studied in this borehole. Three dominant groups of Proteobacteria were found. One of them was found only at $812-820 \mathrm{~m}$, where $63 \%$ of the bacteria belonged to this group. A second existed almost exclusively and also dominating $\left(83 \%\right.$ at $10{ }^{\circ} \mathrm{C}, 65 \%$ at $20^{\circ} \mathrm{C}$ ) at $970-1240 \mathrm{~m}$, and a third was equally distributed between the levels $(17 \%$ at $812-820 \mathrm{~m}, 4 \%$ and $17 \%$ at $970-1240 \mathrm{~m}, 10$ and $20^{\circ} \mathrm{C}$, respectively). The assimilation rates of both $\mathrm{CO}_{2}$ and lactate were faster at the deeper (970-1240 m) compared to the upper level $(812-820 \mathrm{~m})$. The increased rates of the $970-1240 \mathrm{~m}$ population at $20^{\circ} \mathrm{C}$ compared to $10^{\circ} \mathrm{C}$ were most likely an effect of temperature, as the enzyme activities in bacteria usually increase when temperature is raised. The population morphology also differed, according to SEM images, but the population structure was not altered to any great extent by the shift in temperature, as shown by our $16 \mathrm{~S}$ rRNA studies (Ekendahl et al., 1994). The ecosystems sampled thus contained very few species of bacteria showing different metabolic activities and it seems clear that the spatial distribution of bacteria in the rock studied was dependent on the groundwater environment. The $16 \mathrm{~S}$ rRNA analysis supports the conclusion that the studied populations were different in composition.

The origin of the observed bacteria is difficult to determine. Stevens et al. (1993) reported a study on deep groundwater bacteria in drilled artesian wells in Washington, USA, and argued that the anaerobic, alkaline groundwaters favour the growth of aquifer organisms over growth of most contaminants being introduced from the surface. Likewise it can be speculated that the bacteria found were true inhabitants of the Stripa borehole V2. For a more detailed discussion of the origin of these bacterial populations, see Pedersen \& Ekendahl (1992a).

Electron acceptors like oxygen, nitrate and nitrite were not available in amounts likely to dominate the metabolism of the Stripa bacteria. Methanogenic bacteria 
have earlier been proposed to exist in the Stripa groundwater (Pedersen \& Ekendahl, 1992a). They can use $\mathrm{CO}_{2}$ as both carbon source and terminal electron acceptor to produce methane. Both $\mathrm{CO}_{2}$ and methane were present in the waters (Pedersen et al., 1991). However, since no Archaeobacteria were found in the 16S rRNA gene sequencing study (Ekendahl et al., 1994), they should not be abundant, at least in the reactor environment.

It was proposed earlier that since the Stripa bacteria readily assimilated lactate anaerobically (Pedersen \& Ekendahl, 1992a) the dominant species might be sulphatereducing bacteria (SRB). Fritz et al. (1989) used carbon isotope fractionation to draw the conclusion that SRB were present in the Stripa groundwaters. In addition, Fontes et al. (1989) obtained stable isotope data that proved bacterially enhanced redox processes to play an important role in the control of the concentration and heavy isotope contents of aqueous sulphate in Stripa. But sulphate reduction could not be demonstrated, even though sulphate is the most abundant electron acceptor available. Neither could SRB be isolated from the groundwater or from the surfaces (Ekendahl et al., 1994). In the biofilm populations the dominant bacteria belonged to the beta and gamma groups of the Proteobacteria, and not to the delta group, where all known SRB belong (Ekendahl et al., 1994). Therefore the conclusion was made that no or very few SRB were present. This result does not necessarily contradict the stable isotope data. Dating with ${ }^{14} \mathrm{C}$ analysis indicates groundwater ages of 5000-20000 years (Nordström et al., 1985), so the stable isotope profile may have been formed in the past. It is also possible that the sulphate-reducing activity occurred in other geological formations than that intersected by the borehole V2, perhaps during infiltration of surface waters rich in organic carbon.

By comparing the amount of $\mathrm{CO}_{2}$ assimilated during a certain time and the amount of carbon needed to build up a bacterial cell growing during that time, the capability for autotrophy can be evaluated. The values of quotient $Q$ calculated for carbon utilization were between 0.07 and 0.25 (Table 4), indicating that autotrophy could not support the levels of growth observed and that heterotrophy was the dominant carbon transformation process for growth of the studied populations. The $\mathrm{CO}_{2}$ assimilation did not decrease consistently (Table 3 ) when lactate was added, suggesting that there were no autotrophs changing to a heterotrophic metabolism (Hallbeck \& Pedersen, 1991) when organic carbon appeared. The measured $\mathrm{CO}_{2}$ assimilation may thus have been due to heterotrophs using $\mathrm{CO}_{2}$ for anaplerotic reactions to replace intermediates in the tricarboxylic acid cycle (Prescott et al., 1993). It is important to use several different carbon sources for assimilation experiments, as shown in previous Stripa V2 studies (Pedersen \& Ekendahl, 1992a). One reason is that different carbon sources are utilized to varying degrees by the same species. The earlier observed utilizations of added lactate and also glucose, leucine and some formate by parts of the populations (Pedersen \& Ekendahl, 1992a) support the presence of heterotrophs. The Stripa bacteria could further be seen not only to assimilate but also to catabolize lactate and release $\mathrm{CO}_{2}$ (Table 3), which adds to the indications of a heterotrophic dominance in the Stripa environment.

With the laminar flow reactor as a model system, the amount of inorganic carbon (TIC) flowing through a reactor can be compared with the assimilation of $\mathrm{CO}_{2}$ by the attached bacteria. The water flow rates were $66.3 \mathrm{ml} \mathrm{min}^{-1}(812-820 \mathrm{~m})$ and $12.4 \mathrm{ml} \mathrm{min}^{-1}$ (970-1240 m). Multiplying the TIC values from Table 1 with the amount of water flowing through the reactor during $1 \mathrm{~h}$, the TIC flow rates were $200 \mu \mathrm{mol} \mathrm{h}^{-1}$ $(812-820 \mathrm{~m})$ and $42 \mu \mathrm{mol} \mathrm{h}^{-1}$ (970-1240 m). Using $1.8 \times 10^{6}$ bacteria $\mathrm{cm}^{-2}$ as a common value for bacterial density (Table 3), there were $1.45 \times 10^{9}$ bacteria per reactor growing on a surface area of $806.4 \mathrm{~cm}^{2}$. The $\mathrm{CO}_{2}$ assimilation data from Table 3 were then multiplied by the numbers of bacteria in the reactor to give the total assimilation during $1 \mathrm{~h}$. These values of total assimilation in the reactor were divided by the TIC flow rate values; the results show that the bacteria assimilated between $10^{-5}$ and $4 \cdot 4 \times 10^{-4}$ of the TIC passing through with the water.

Moving from our reactor model system to a typical hard rock fracture, the water flow rate and the volume/surface area ratio will decrease. Since channelling of the groundwater has been suggested to dominate in bed-rock (Moreno et al., 1988; Pedersen \& Ekendahl, 1992a; Tsang et al., 1988) we assumed a fracture width of $0 \cdot 1 \mathrm{~mm}$ with sides of $1 \mathrm{~cm}^{2}$ (Moreno et al., 1988) and used TIC values from Table 1 and bacterial density and assimilation data from Table 3 in the following calculations. At the $812-820 \mathrm{~m}$ level, the flow rate was $2.8 \mathrm{~mm} \mathrm{~s}^{-1}$ (Table 1) and it would take $3.57 \mathrm{~s}$ for $0.01 \mathrm{ml}$ of water to pass a channel area of $2.02 \mathrm{~cm}^{2}$. During that time $4.3 \times 10^{-15} \mathrm{~mol}$ $\mathrm{CO}_{2}$ would be assimilated by the attached bacteria. The quotient between this calculated figure and the measured TIC $(0.5 \mathrm{nmol}$ in $0.01 \mathrm{ml}$ of water, from Table 1) is $8.7 \times 10^{-6}$. Thus, during $3.57 \mathrm{~s}$, one part out of approximately $115000\left(1 / 8.7 \times 10^{-6}\right)$ of the TIC in the water would be utilized for each $\mathrm{cm}$ of bed-rock channel through which the groundwater flows. Considering a 'plug flow' (the water moves without mixing with new water), the TIC would be depleted after a flow distance of $1.15 \mathrm{~km}$ or after $115 \mathrm{~h}$, provided no addition of carbonate from degradation of organic matter or dissolution of mineral occurred. The values for the $970-1240 \mathrm{~m}$ level (flow rate $0.5 \mathrm{~mm} \mathrm{~s}^{-1}$ ) at $10^{\circ} \mathrm{C}$ and $20^{\circ} \mathrm{C}$ were $176 \mathrm{~m}$ and $98 \mathrm{~h}$ and $22 \mathrm{~m}$ and $12 \mathrm{~h}$, respectively. It becomes obvious that the measured $\mathrm{CO}_{2}$ assimilation must have been balanced by a respiratory activity, indicated by the autotrophy quotients (Table 4) to be 4-14 times larger than the $\mathrm{CO}_{2}$ assimilation activity. Indeed, the biofilm bacteria studied respired added lactate and the $\mathrm{CO}_{2}$ released represented $7 \times 10^{-5}$ to $1.8 \times 10^{-4}$ of the TIC flowing through the reactors, but this figure is lower than the $\mathrm{CO}_{2}$ assimilation calculated above $\left(10^{-5}\right.$ to $\left.4.4 \times 10^{-4}\right)$. The biofilm bacteria obviously must have metabolized organic carbon compounds present in the groundwater 
other than lactate if a steady state between assimilated and produced $\mathrm{CO}_{2}$ is anticipated.

There was typically between 30 and $300 \mu \mathrm{mol} \mathrm{l}^{-1}$ of dissolved organic carbon in the groundwaters studied and also methane. About $50 \%$ of this dissolved organic carbon was composed of complex humic and fulvic acids (Pettersson et al., 1990), and a smaller part was organic substances with shorter carbon chains than glucose. The sources of this organic carbon are unexplored. It could be organic material percolating down from the ground surface, but as dating with ${ }^{14} \mathrm{C}$ analysis indicates groundwater ages of 5000-20000 years (Nordström et al., 1985), this seems unlikely. The other possible source would be organic deposits in the rock or organic compounds migrating up from very deep layers of the earth (Gold, 1992). It will be an important task to investigate the sources and fluxes of organic carbon in the subterranean environment. The results presented here indicate that organic carbon is the main fuel for bacterial processes of importance to nuclear waste disposal and the fluxes will then determine the process rates. Investigations of bacterial carbon transformations and the ecology of important groups of deep granitic groundwater bacteria will be continued and are now concentrated on the environment around the Äspö Hard Rock Laboratory (Gustafsson et al., 1988, 1989, 1991) now under construction on the Swedish east coast.

\section{ACKNOWLEDGEMENTS}

We thank our mine guide, Birger Ekstrand, and the director of the mine, Gunnar Ramqvist, for pleasant collaboration at the Stripa mine, and Johanna Arlinger for her enthusiastic technical assistance and for comments on the manuscript. This research was supported by the Swedish Nuclear Fuel and Waste Management Co.

\section{REFERENCES}

Carritt, D. E. \& Carpenter, J. H. (1972). Dissolved oxygen concentration and saturation. In New Baltic Manual with Methods for Sampling and Analyses of Pbysical, Chemical and Biological Parameters (Coop. Research Report, series A:29), pp. 24-29. Edited by S. R. Carlberg. Charlottenlund, Denmark: International Council for the Exploration of the Sea.

Ekendahl, S., Arlinger, J., Stăhl, F. \& Pedersen, K. (1994). Characterization of attached bacterial populations in deep granitic: groundwater from the Stripa research mine by $16 \mathrm{~S}$ rRNA gene: sequencing and scanning electron microscopy. Microbiology 140, 1575-1583.

Erlich, H. L. (1990). Geomicrobiology. 2nd edn. New York: Marcel Dekker.

Escher, A. \& Characklis, W. G. (1990). Modeling the initial events in biofilm accumulation. In Biofilms, pp. 445-486. Edited by W. G. Characklis \& K. C. Marshall. Chichester: John Wiley \& Sons.

Fontes, J. C., Fritz, P., Louvat, D. \& Michelot, J. L. (1989). Aqueous sulfates from the Stripa groundwater system. Geochim Cosmochim Acta 53, 1783-1790.

Fossing, H. \& Jörgensen, B. B. (1989). Measurement of bacterial sulfate reduction in sediments: evaluation of a single step chromium reduction method. Biogeochemistry 8, 205-222.
Franson, M. A. H. (1985). Standard Methods for the Examination of Water and Wastewater, 16th edn. Washington, DC: AWWA-APHAWPCF.

Fritz, P., Fontes, J.-C., Frape, S. K., Louvat, D., Michelot, J.-L. \& Balderer, W. (1989). The isotope geochemistry of carbon in groundwater at Stripa. Geochim Cosmochim Acta 53, 1765-1775.

Gold, T. (1992). The deep hot biosphere. Proc Natl Acad Sci US A 89, 6045-6049.

Grigorova, R. \& Norris, J. R. (1990). Size estimation. Methods in Microbiology 22, 56-67.

Gustafsson, G., Stanfors, R. \& Wikberg, P. (1988). Swedish Hard Rock Laboratory first evaluation of preinvestigations 1986-1987 and target area characterization. SKB Technical Report 88-16, Stockholm. Available from SKB, Box 5864, 10248 Stockholm, Sweden, tel. +4686652800.

Gustafsson, G., Stanfors, R. \& Wikberg, P. (1989). Swedish Hard Rock Laboratory first evaluation of preinvestigations 1988 and target area characterization. SKB Tecbnical Report 89-16, Stockholm. Available from SKB, Box 5864, 10248 Stockholm, Sweden, tel. +4686652800 .

Gustafsson, G., Liedholm, M., Rhén, I., Stanfors, R. \& Wikberg, P. (1991). Äspö Hard Rock Laboratory. Predictions prior to excavation and the process of their validation. SKB Technical Report 91-23, Stockholm. Swedish Nuclear Fuel and Waste Management Co., Box 5864, S-10248 Stockholm.

Hallbeck, L. \& Pedersen, K. (1991). Autotrophic and mixotrophic growth of Gallionella ferruginea. J Gen Microbiol 137, 2657-2661.

Huffman, E. D. W. (1977). Performance of a new automatic carbon dioxide coulometer. Microchem J 22, 567-573.

Moreno, L., Tsang, Y. W., Tsang, C. F., Hale, F. V. \& Neretnieks, I. (1988). Flow and tracer transport in a single fracture. A stochastic model and its relation to some field observations. Water Resour Res 24, 2033-2048.

Neidhardt, F. C., Ingraham, J. L. \& Schaechter, M. (1990). Pbysiology of the Bacterial Cell: a Molecular Approach, pp. 1-29. Sunderland, MA: Sinauer Associates.

Nordström, D. K., Andrews, J. N., Carlsson, L., Fontes, J.-C., Fritz, P., Moser, H. \& Olsson, T. (1985). Stripa Project Technical Report 8506. Swedish Nuclear Fuel and Waste Management Co., Box 5864, Stockholm.

Pedersen, K. (1982). Method for studying microbial biofilms in flowing-water systems. Appl Environ Microbiol 43, 6-13.

Pedersen, K. (1993). The deep subterranean biosphere. J Earth S $c i$ Rev 34, 243-260.

Pedersen, K. \& Albinsson, Y. (1992). Possible effects of bacteria on trace element migration in crystalline bed-rock. Radiocbim Acta 58/59, 365-369.

Pedersen, K. \& Ekendahl, S. (1990). Distribution and activity of bacteria in deep granitic groundwaters of southeastern Sweden. Microb Ecol 20, 37-52.

Pedersen, K. \& Ekendahl, S. (1992a). Incorporation of $\mathrm{CO}_{2}$ and introduced organic compounds by bacterial populations in groundwater from the deep crystalline bedrock of the Stripa mine. J Gen Microbiol 138, 369-376.

Pedersen, K. \& Ekendahl, S. (1992b). Assimilation of $\mathrm{CO}_{2}$ and introduced organic compounds by bacterial communities in groundwater from Southeastern Sweden deep crystalline bedrock. Microb Ecol 23, 1-14.

Pedersen, K., Holmström, C., Olsson, A.-K. \& Pedersen, A. (1986). Statistic evaluation of the influence of species variation, culture 
conditions, surface wettability and fluid shear on attachment and biofilm development of marine bacteria. Arch Micrabiol 145, 1-8.

Pedersen, K., Ekendahl, S., Ståhl, F. \& Arlinger, J. (1991). Microbes in crystalline bedrock: assimilation of $\mathrm{CO}_{2}$ and introduced organic compounds by bacterial populations in groundwater from deep crystalline bedrock at Laxemar and Stripa. SKB Technical Report 9156, Swedish Nuclear Fuel and Waste Management Co., Box 5864, S-10248 Stockholm, Sweden.

Pettersson, C., Ephraim, J., Allard, B. \& Borén, H. (1990). Characterization of humic substances from deep groundwaters in granitic bedrock in Sweden. SKB Technical Report 90-29. Swedish Nuclear Fuel and Waste Management Co., Box 5864, S-10248 Stockholm.

Prescott, L. M., Harley, J. P. \& Klein, D. A. (1993). The use of energy in biosynthesis. In Microbiology, 2nd edn, pp. 171-190. Edited by K. Kane. Dubuque, IA: Wm C. Brown Publishers.

SKB (1991). SKB Annual Report 1991. Including summaries of technical reports issued during 1991. SKB Technical Report 91-64, Swedish Nuclear Fuel and Waste Management Co., Box 5864, S10248 Stockholm, Sweden.
Stanier, R. Y., Ingraham, J. L., Wheelis, M. L. \& Painter, P. R. (1990). General Microbiology, 5th edn. London: MacMillan Education.

Stevens, T. O., McKinley, J. P. \& Fredrickson, J. K. (1993). Bacteria associated with deep, alkaline, anaerobic groundwaters in southeast Washington. Microb Ecol 25, 35-50.

Tsang, Y. W., Tsang, C. F., Neretnieks, I. \& Moreno, L. (1988). Flow and tracer transport in fractured media. A variable aperture channel model and its properties. Water Resour Res 24, 2049-2060.

West, J. M., Christofi, N. \& Chapman, N. A. (1982). Microbes in deep geological systems and their possible influence on radioactive waste disposal. Radioactive Waste Management and Nuclear Fuel Cycle 3, 1-15.

West, J. M., Christofi, N. \& McKinley, I. G. (1985). An overview of recent microbiological research relevant to the geological disposal of nuclear waste. Radioactive Waste Management and Nuclear Fuel Cycle 6, 79-95.

Received 12 October 1993; revised 5 January 1994; accepted 14 January 1994. 